\title{
Location and distribution pattern of nitric oxide synthesizing neuronal cells in the digestive tract and urinary bladder of mice
}

\author{
Ahmad Aulia Jusuf
}

\begin{abstract}
Abstrak
Dalam rangka menyelidiki lebih lanjut lokasi dan pola penyebaran sel saraf yang mengandung enzim "nitric oxide synthase" (NOS) pada susunan saraf perifer otonom saluran cerna dan kandung kemih, organ tersebut diwarnai dengan teknik histokimia untuk mendeteksi NADPH diaforase. Sejumlah kelompokan sel yang positif terhadap pewarnaan NADPH diaforase terdeteksi di semua bagian saluran cerna, yaitu esofagus, lambung, usus halus, dan usus besar. Selain itu, sel tersebut juga terdeteksi pada kandung kemih. Sel-sel ini hadir dalam jumlah yang sangat sedikit pada lapisan submukosa (pleksus submukosa Meissner/ "submucous plexus of Meissner") dan dalam jumlah banyak pada daerah antara lapis dalam dan luar otot polos saluran cerna (pleksus mienterikus Auerbach/"myenteric plexuses of Auerbach"). Pada kandung kemih, sel tersebut terletak pada leher kandung kemih ("bladder neck"), dan pada lapisan otot polos sebelah dalam. Karena jumlah sel saraf yang mengandung NADPH diaphorase per milimeter persegi lebih banyak terdapat di lambung dan usus besar, ada kemungkinan kadar "nitric oxide" di organ tersebut juga lebih banyak. Hal ini mengesankan fungsi nitric oxide (NO) yang cukup penting di organ-organ tersebut. Selanjutnya, keberadaan sel-sel tersebut pada daerah leher kandung kemih ("bladder neck") mungkin menunjukkan bahwa "nitric oxide" (NO) berperan pada fungsi otot sfingter vesiko-uretra ("vesico-urethral sphincter muscle").
\end{abstract}

\begin{abstract}
In order to investigate further the location and distribution pattern of NOS containing neuronal cells in the peripheral autonomic nerve system of digestive tract and urinary bladder, the digestive and bladder organs were stained by NADPH diaphorasehistochemical staining. Some groups of NADPH diaphorase positive neuronal cells were detected along all parts of the digestive tract. including esophagus, stomach, small and large intestine, as well as urinary bladder. In the digestive tract, these cells were existed in a very small number in the submucous layer (submucous plexuses of Meissner) and ubiquitous in the area between the external and internal layer of smooth muscle (myenteric plexuses of Auerbach). In the bladder, those cells existed at the bladder neck, and in the inner layer of the muscle of urinary bladder. Since the number of NADPH diaphorase containing neuronal cells per millimeter square is more numerous in stomach and large intestine, there is a possibility that the amount of nitric oxide in those organs is also higher. These facts suggest an important role for nitrict oxice (NO) in those organs. Furthermore, the existence of those cells in the limited area of urinary bladder i.e. in the bladder neck may suggest the role of nitric oxide (NO) in vesico-urethral sphincter muscle function.
\end{abstract}

Keywords: NADPH diaphorase, nitric oxide synthase, submucous plexuses of Meissner, myenteric plexuses of Auerbach, bladder neck

Nitric oxide (NO) is a simple gas with free radical chemical properties, but it is often confused with the chemically distinct nitrous oxide $\left(\mathrm{N}_{2} \mathrm{O}\right)$ which is used as an anesthetic and is chemically stable. Nitric oxide is an important messenger molecule produced by endothelial cells, neurons, skeletal muscle, neutrophils, macrophages, pancreatic islets, endometrium,

Department of Histology, Faculty of Medicine, University of Indonesia, Jakarta, Indonesia

International Center for Medical Research (ICMR), School of Medicine. Kobe Universitv. Kusunoki-cho 7 Chome 5-1 Chuo-ku. Kobe, Japan 260,E-mail address : jusuf@med.kobe-u.ac.jp epithelium of respiratory and gastrointestinal tract, and others. ${ }^{1}$ Nitric oxide is an unusual mediator because it is a gas with unknown storage mechanism. It diffuses freely across membranes, and is extremely labile with a biological half life on the order of seconds.

No binds to and activates soluble guanylyl cyclase resulting in increased cGMP level. The exact mechanism by which cGMP exerts its biological effects are still unknown, although cGMP dependent protein kinases may be involved. Nitric oxide also modifies a critical cysteine in glyceraldehyde 3phosphate dehydrogenase by adenosine diphosphate ribosylation, ${ }^{2,3}$ or S-nitrosylation via NAD interactions. ${ }^{4}$ 
Nitric oxide also binds to a variety of iron- and sulfurcontaining proteins. ${ }^{5}$

Nitric oxide is synthesized via catalytic actions of nitric oxide synthase (NOS). Several homologous but separate genes code for neuronal NOS (nNOS), endothelial NOS (eNOS), and macrophage-derived NOS (also known as inducible NOS/iNOS). ${ }^{5}$ Neuronal NOS and endothelial NOS are produced constitutively and are calmodulin dependent; their activity are stimulated by calcium. Those enzymes also needed reduced nicotinamide adenin dinucleotide phosphate (NADPH) as an electron donor in their catalytic activity. Inducible NOS are produced inducibly by glucocorticoid and cytokines like gamma interferon and lipopolysaccharide, and does not depend on calcium for its activity. ${ }^{6}$ All forms of NOS use arginine as their substrate, and form NO and citrulline stoichometrically.

In neurons, NOS colocalize with NADPH diaphorase. ${ }^{7,8}$ Hope et $\mathrm{al}^{9}$ also presented strong evidence for the idea that NADPH diaphorase may correspond to neuronal nitric oxide synthase. This NADPH- and $\mathrm{CA}^{2+}$ / Calmodulin-dependent enzyme (NOS) forms NO by conversion of arginine to citruline. ${ }^{10}$ In the presence of NADPH diaphorase, the reduced form of nitric oxide synthase can catalyze the conversion of a soluble tetrazolium to an insoluble visible formazan. ${ }^{11}$ This multiple step reaction used in NADPH diaphorase histochemical staining is illustrated in the schematic figure below. ${ }^{12}$

This NADPH diaphorase histochemical staining is resistant to formaldehyde fixation and displays the cahracteristics of an enzymatic reaction. ${ }^{14}$

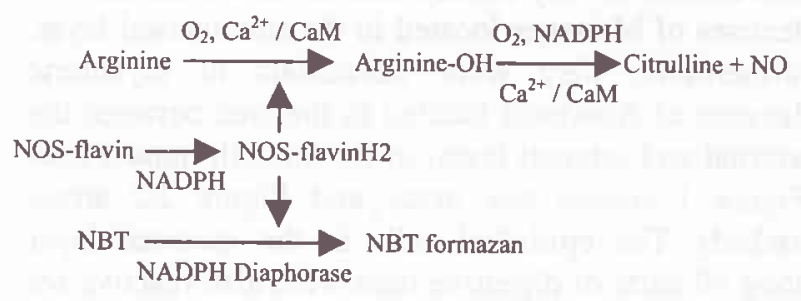

CaM $=$ calmodulin

NADPH = nicotinamide adenin dinucleotide phosphate

NO = nitric oxide

NOS $=$ nitric oxide synthase

NBT $=$ Nitro blue tetrazolium

NOS initially receives the electrons from NADPH in a calcium/calmodulin- and arginine-independent step that presumably involves reduction of one or both of the associated flavins. The reduced NOS will be rapidly re-oxidized in the presence of an appropriate electron acceptor, such as nitro blue tetrazolium (NBT). In the presence of calcium, calmodulin and molecular oxygen, the reduced NOS will hydroxylate the guanidino group of arginine in a P-450 like monooxygenase reaction. ${ }^{13}$ The tightly associated hydroxyarginine is then further oxidized by NOS to citrulline and NO.

In the nervous system, nNOS is located to discrete populations of neurons in the cerebellum, olfactory bulb, hippocampus, cortex, striatum, basal forebrain, and brainstem. NOS is also concentrated in the posterior pituitary gland, supra-optic and paraventricular hypothalamic nuclei, and in discrete ganglion cells of the adrenal medulla. ${ }^{15}$

The localization and distribution pattern of NOS containing neuronal cells in the peripheral autonomic nervous system, especially in the digestive tract and urinary bladder are still unclear. Gabella et al.$^{16}$ failed to detect intramural ganglia in the urinary bladder of the mouse. However, Grozdanovic et al ${ }^{17}$ claimed that they had succesfully demonstrated the occurrence of intramural neurons in the lower urinary tract of the mouse. The knowledge of localization and distribution pattern of NOS containing neuronal cells in the digestive tract and urinary bladder will give implication and more stimulation to study the role of nitric oxide on the function of the digestive tract and urinary bladder.

In order to investigate further the localization and distribution pattern of NOS containing neuronal cells in the peripheral autonomic nervous system of digestive tract and urinary bladder, we stained both whole mount and sections of those organs with NADPH diaphorase histochemical staining and counted the number (density) of positive cells permillimeter square in the digestive tract and the total number of those cells in the urinary bladder. We also discussed the possible function of NO in those organs and the possible correlation between the localization and distribution pattern of those positive cells and their natural functions.

\section{METHODS}

\section{Animal}

Mice (C57BL/6xDBA/2, F1 mice) were purchased from Japan SLC (Hamamatsu, Japan). Mice were 
maintained in the animal center in a specific pathogen free condition. In this experiment 3 male and 3 female mice were used in both group (the experimental and control group).

\section{Sectioned NADPH diaphorase histochemical staining}

Using a wing needle, mice were cardiacly perfused with $0.1 \mathrm{M}$ phosphate buffer $(\mathrm{pH} 7.4)$ containing $4 \%$ paraformaldehyde. The isolated tissues were then post-fixed with $4 \%$ paraformaldehyde equilibrated with $20 \%$ sucrose, for 12 hours. Tissue blocks for cryostat sections were prepared by embedding each tissue into a tissue compound and allowed them to be harden in the cryostat chamber. Using a cryostat, these blocks were sectioned at $10 \mu \mathrm{m}$, and mounted on the glass slides. The slides were then washed with $0.1 \mathrm{M}$ phosphate buffer ( $\mathrm{pH} 7.4$ ) for 3-5 minutes, and put on the rack underlied with wet paper towel.

In the experimental group, after washing, the slides were incubated in $0.1 \mathrm{M}$ phosphate buffer ( $\mathrm{pH} 7.4$ ) containing $1.0 \mathrm{mg} / \mathrm{ml} \beta-N A D P H$ (Sigma, St. Louis, MO), $0.1 \mathrm{mg} / \mathrm{ml}$ nitro blue tetrazolium (NBT) and $0.3 \%$ Triton $\mathrm{X}-100$, for 60 minutes, at $37^{\circ} \mathrm{C}$. In the control group, the same procedure were performed, except the last step. After washing, the control slides were incubated in $0.1 \mathrm{M}$ phosphate buffer $(\mathrm{pH}$ 7.4) containing only $0.1 \mathrm{mg} / \mathrm{ml} \mathrm{NBT}$ and $0.3 \%$ Triton X100 , for 60 minutes, at $37^{\circ} \mathrm{C}$.

\section{Whole mount NADPH diaphorase histo-chemical staining}

Digestive and urinary bladder tissues were isolated from cardiacly perfused mice as described above, and post fixed with $4 \%$ paraformaldehyde for 12 hours. In the experimental group, after washing with PBS, whole tissues were incubated with $0.1 \mathrm{M}$ phosphate buffer (pH 7.4) containing $1.0 \mathrm{mg} / \mathrm{ml} \quad \beta-\mathrm{NADPH}$ (Sigma, St. Louis, MO), $0.1 \mathrm{mg} / \mathrm{ml}$ nitro blue tetrazolium and $0.3 \%$ Triton X-100, for $90-120$ minutes, at $37^{\circ} \mathrm{C}$. In control group, after washing with PBS, whole tissues were incubated with $0.1 \mathrm{M}$ phosphate buffer (pH 7.4) containing only $0.1 \mathrm{mg} / \mathrm{ml} \mathrm{NBT}$ and $0.3 \%$ Triton $\mathrm{X}-100$, for $90-120$ minutes, at $37^{\circ} \mathrm{C}$.

\section{The Number of NADPH diaphorase positive neuronal cells}

The number of NADPH diaphorase positive neuronal cells in the urinary bladder is very little (only a single cell or a cluster of ganglion cells) while they were particularly numerous in the bladder neck regions. Therefore, in the whole mount samples, total number of those cells was counted directly in all microscopic fields, under light microscope. The number permillimeter square (density) of those cells in several different parts of the digestive tract were counted by using enlargement of microphotographs of defined organs. The average and standard deviation values of the density or total number of those positive cells in the different parts of the digestive tract or urinary bladder were statistically calculated from 6 different observed animals.

\section{RESULT}

To investigate the localization and distribution pattern of nitric oxide synthesizing neuronarl cells in the digestive tract and urinary bladder, histochemical staining method to detect NADPH diaphorase was performed. The diaphorase positive neuronal perikarya, neuronal fibers and epithelium cells of the mucosal layer showed blue precipitates obtained from the conversion of nitro blue tetrazolium into NBT formazan (Figure 1 and 2). These blue precipitates were clearly located only in the cytoplasm of neuronal cells and their nerve fibers.

\section{Digestive tract}

The numerous groups of NADPH diaphorase positive neuronal cells were detected along all part of the digestive tract, including esophagus, stomach, and small and large intestine (Figure1 and 2A,C). These cells existed in very limited number in the submucous plexuses of Meissner located in the submucosal layer. Furthermore, they were ubiquitous in myenteric plexuses of Auerbach located in the area between the external and internal layer, of the smooth muscle coat (Figure 1 square box areas, and Figure 2C arrow marked). The epithelial cells in the mucosal layer along all parts of digestive tract were also reactive for this NADPH diaphorase histochemical staining. No NADPH diaphorase positive cell was found in the digestive tissues of the control samples.

In the large intestine (Figure 2A and C) many diaphorase positive neuronal perikarya were located within the primary meshwork of the myenteric plexus of Auerbach, and in the area between the external and internal layer of the muscle coat. These neuronal cells 
gave the innervation to the muscle layer of the digestive tract through the neurites and also to the submucous plexus of Meissner. The neuronal fibers which connected the neuronal cells one another could be detected more clearly in the large intestine than those in the other parts of the digestive tract. These NADPH diaphorase positive neuronal cells belong to bipolar and multi-polar neuronal cells (Figure 1 and 2 A, C).

\section{Urinary bladder}

Neuronal perikarya staining for NADPH diaphorase particularly existed in the urinary bladder at the bladder base and bladder neck region (around the ureteral orifices and in the floor of the bladder). These cells were located inside of the muscle coat of the bladder wall (Figure 2B and D). As in the digestive tract, these NADPH diaphorase positive cells had also fibers that connected the neuronal cells one to another. Epithelial cells of urinary bladder (urothelium) also exhibited positive reaction for NADPH diaphorase staining. All of the control samples exhibited negative reaction for NADPH diaphorase staining.

\section{The number of NADPH diaphorase reactive cells in the digestive tract and urinary bladder}

The number of NADPH diaphorase positive neuronal cells varied among parts of the digestive tract. The density of those positive cells was higher in the large intestine and was very low in the esophagus (Figure 3 ). Since the number of those positive cells was very little in the bladder, we counted all of the positive cells presented in the bladder directly from the whole mount samples under light microscopy. The density of those cells per-millimeter square in the different parts of digestive tract were $9 \pm 0.54$ (esophagus); $45 \pm$ 3.89 (stomach); $31 \pm 1.14$ (small intestine); and $121 \pm$ 12.63 (large intestine). Mean-while, the total number of those cells in the urinary bladder was $59 \pm 14.35$.

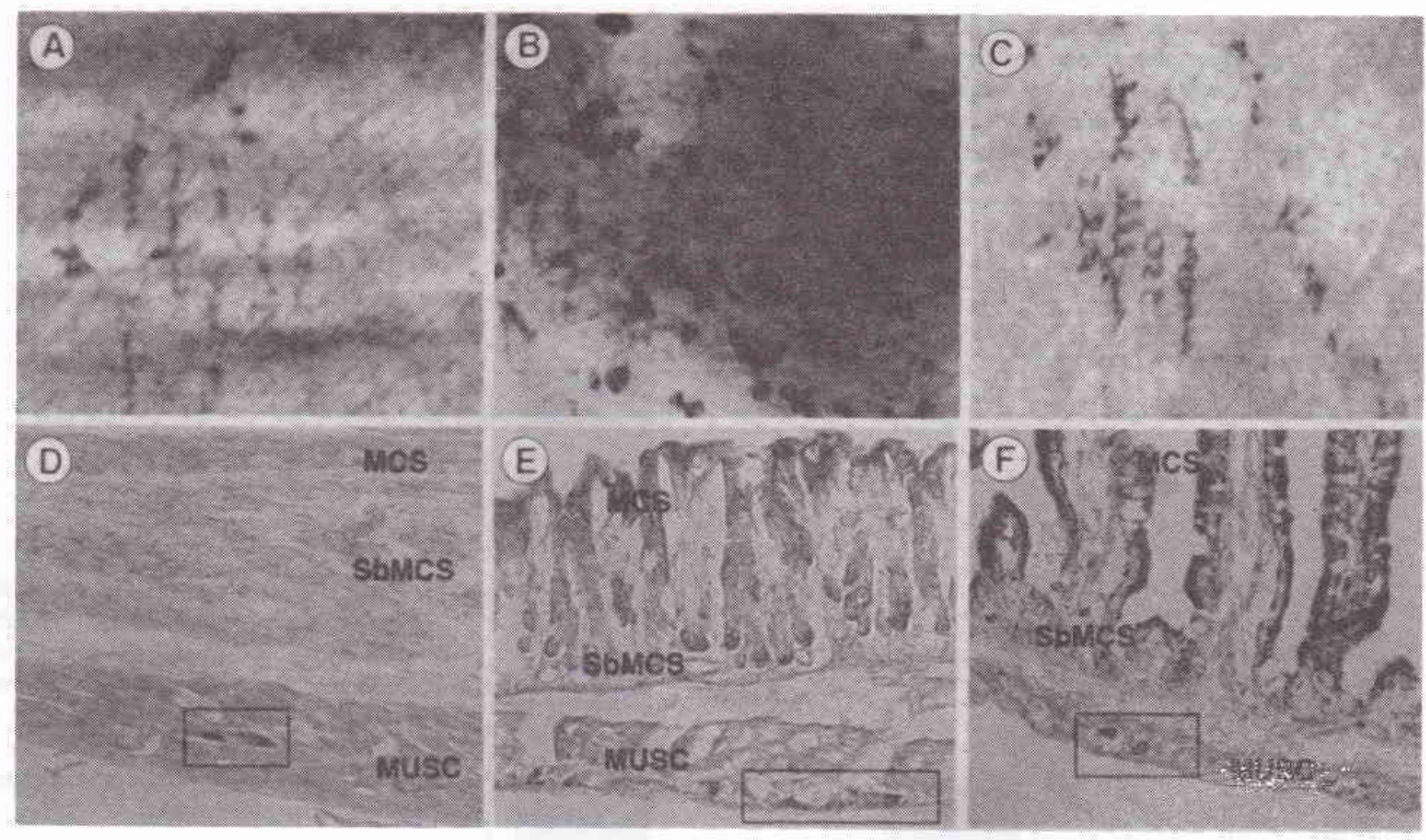

Figure 1. Microphotographs of NADPH diaphorase positive neuronal cells in the esophagus (A and D), stomach (B and E), and small intestine $(C$ and $F) .(A, B$, and $C)$ are whole mount staining; $(D, E$, and $F)$ are sectioned-NADPH diaphorase histochemical staining. The areas in the small square-boxes $(D, E$, and $F)$ indicate the location of neuronal cells with positive NADPH diaphorase histochemical staining. MCS, SbMCS, and MUSC indicate the mucous, submucous, and muscle layers. Magnification: 60x (A, B, and C); $20 \times(D, E$, and $F)$. 


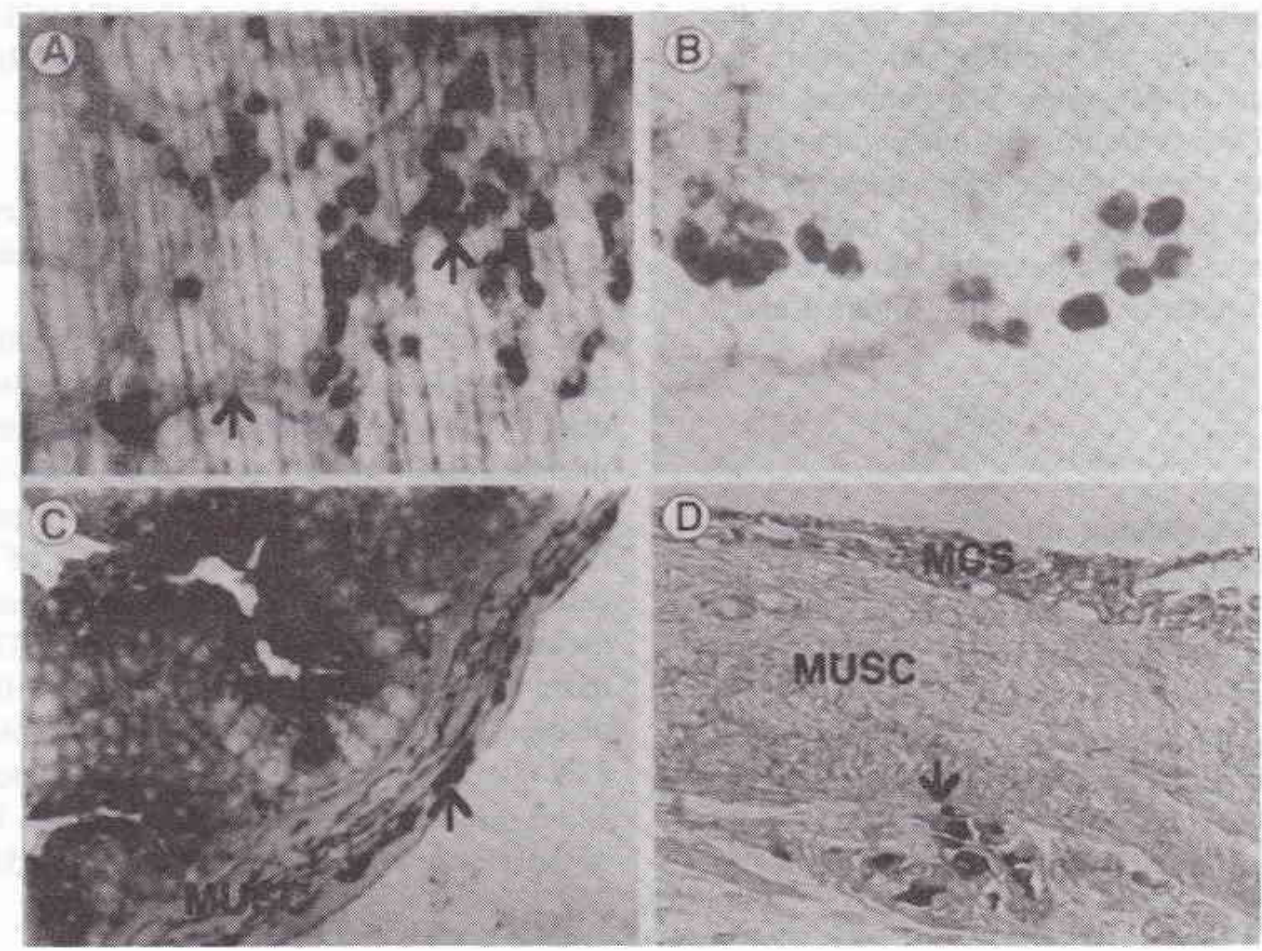

Figure 2. Microphotographs of NADPH diaphorase positive neuronal cells in the large intestine ( $A$ and $C$ ) and urinary bladder ( $B$ and $D)$. ( $A$ and $B$ ) are whole mounstaining; ( $C$ and $D$ ) are sectioned-NADPH diaphorase histochemical staining. Arrow marks indicate the location of the NADPH diaphorase positive fibers and neuronal cells in large intestine $(A$ and $B)$, and urinary bladder ( $B$ and $D)$. MCS, and MUSC indicate the mucous and muscle layer. Magnification: $100 x$ (A and B); $20 x(C)$, and $50 x(D)$.

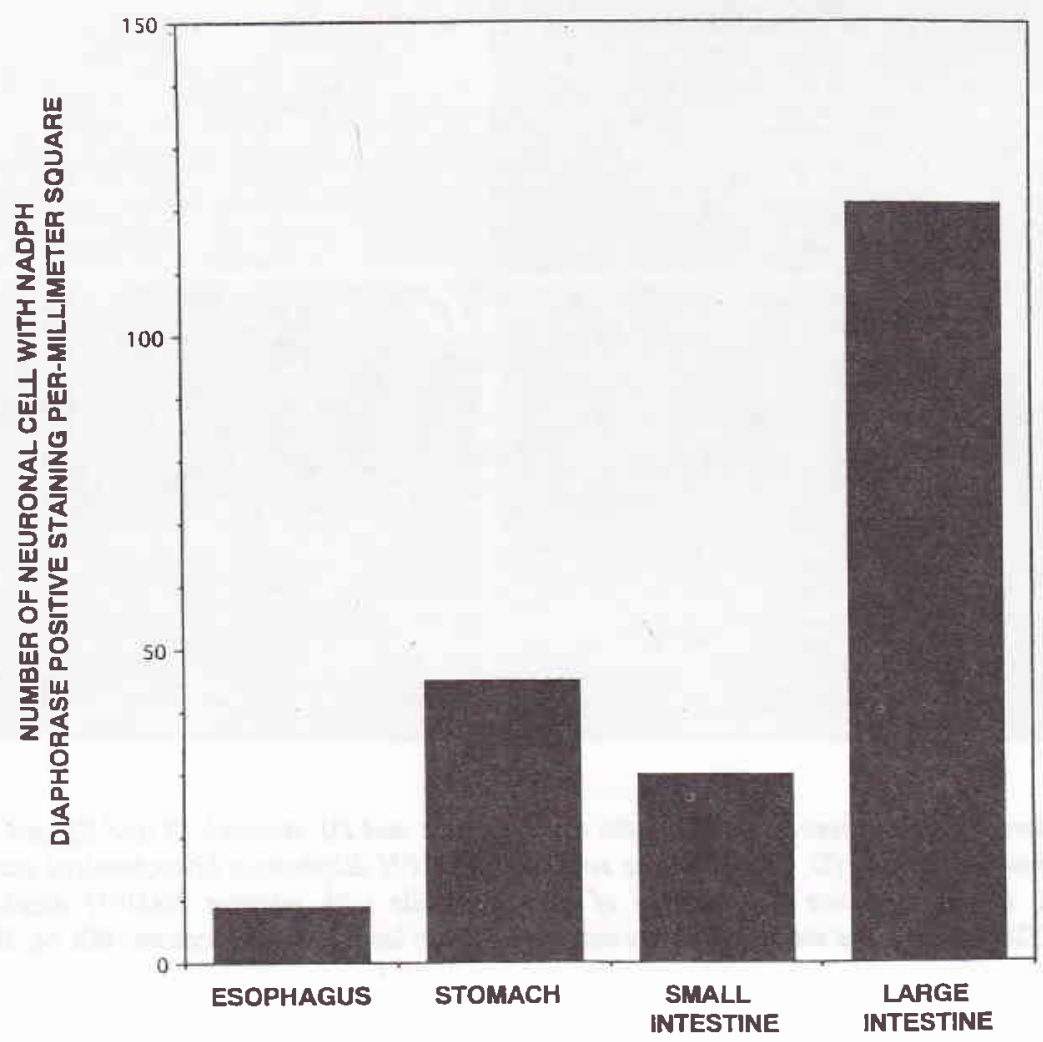

Figure 3. Bar-graphic diagram of the number of neuronal cells with NADPH diaphorase positive staining permillimeter square in several different parts of digestive tract. The density of neuronal cells per-millimeter square is highest in the colon (large intestine) and lowest in the esophagus. 


\section{DISCUSSION}

The location of the blue precipitates in the cytoplasm and nerve fibers indicate that nitric oxide synthase (NOS) and NADPH diaphorase belongs to cytoplasmic proteins. However, not only the neuronal cells, the epithelium cells of mucosal layer in the digestive tract and urinary bladder were also positively stained. These results were similar to the other previous reports. ${ }^{17}$ So far, there is no report describing whether these cells really contain nitric oxide synthase or not. The correlation between the existence of positive NADPH diaphorase staining in the epithelium layer and their function is still poorly understood. In their histochemical studies, Bredt et $\mathrm{al}^{15}$ could not find nitric oxide synthase in parenchymal or stromal cells of the liver, heart, lung, spleen, kidney, thymus, testis, or salivary glands. Despite these observations, it can not be excluded that mucosal NADPH diaphorase (that represents an isoform of nitric oxide synthase) is not readily detectable with the antisera raised against the neuronal nitric oxide synthase. In fact, these antisera did not react with nitric oxide synthase of activated macrophages. Furthermore, if the epithelium cells really contain nitric oxide, it is supposed that NO is involved in the cellular process of epithelium cells.

Although NADPH diaphorase activity was detected in certain nerve cells and neuronal processes along the digestive tract (Figure 1), the greatest density of diaphorase positive neuronal cell, which was indicated as the number of NADPH diaphorase positive neuronal cells per-millimeter square (Figure 3 ), was found in the large intestine, followed by that in stomach. The NADPH diaphorase positive enteric neuronal cells in the sub-mucous layer were also easier to be identified in the large intestine (Figure 2 $A$ and $C$ ). Since the number of NADPH diaphorase positive neuronal cell was higher in stomach and large intestine than in other parts of the digestive tract (Figure 3), it is supposed that nitric oxide (NO) as a neurotransmitter is required in a larger amount by the smooth muscle of the stomach and large intestine for their adequate movement or peristalsis during the digestion process of food in the stomach and the excretion process of feces from the large intestine.

Several studies revealed that nitric oxide, which was released from inhibitory non-adrenergic non-cholinergic nerve, served as an inhibitory non-adrenergic noncholinergic (NANC) neurotransmitter ${ }^{18}$ in several autonomic functions. Nitric oxide is involved in mediating relaxation of smooth muscles of the digestive tract, ${ }^{19,20}$ which is necessary for facilitating the passage of material, changing food to a bolus and generating peristalsis in the digestive tract. ${ }^{18-20}$ Mice lacking the nitric oxide synthase (NOS) gene exhibited grossly enlarged stomachs, with hypertrophy of the pyloric sphincter and the circular muscle layer. ${ }^{19}$ Meanwhile, mice with hyperinnervation of NADPH diaphorase positive enteric neuronal cells exhibited megacolon phenomena with prolonged transit time of barium throughout the gastrointestinal tract during barium enema (our unpublished data).

The NADPH diaphorase positive neuronal cells in the urinary bladder consisted of single cell or group of cells, which were particularly numerous in the region of bladder base or bladder neck (around the ureteral orifices and in the floor of the bladder). Those cells, which are located in the wall of urinary bladder are considered to be the source of the parasympathetic post-ganglionic nerve supply to this organ. ${ }^{17}$ Since the vesico-urethral sphincter muscle is also located almost in the same area as NADPH diaphorase positive neuronarl cells, nitric oxide is thought to be a neurotransmitter necessary for facilitating the relaxation of vesico-urethral sphincter. ${ }^{18,19}$ However, its exact function in vivo remains ill-defined. Studies in fetal sheep demonstrated that nitric oxide inhibition caused bladder hyperactivity and increased bladder capacity, perhaps by preventing sphincter relaxation. ${ }^{21}$ In rat, inhibitors of the NO system caused bladder hyperactivity and decreased bladder capacity. ${ }^{22}$ In our observations, mice with hyper-innervation of NADPH diaphorase positive neuronal cells showed decreased bladder capacity and decreased threshold pressure, perhaps by hyperrelaxation of vesico-urethral sphincter muscle (our unpublished data).

The exact function and role of nitric oxide (NO) as a nonadrenergic noncholinergic (NANC) neurotransmitter in various tissues and organs of the body is still far from understood. The pharmacological effects of nitrates are used in clinical conditions, e.g. ischemic heart diseases, hypertension, and motor disorders of esophagus. Furthermore, nitroglycerin is used in Germany (and possibly also in other places) as an antispasmodic agent in patient complaining of biliary colic. These observations are interesting because recent animal studies suggest that the cholexystokinininduced relaxation of the sphincter of Oddi is mediated by the NANC neural pathway operated by an unidentified transmitter substance. ${ }^{23}$ Bumett et al $^{24}$ reported that NO was a physiologic mediator of erectile function. Neuronal NOS (nNOS) was located 
in rat penile neurons innervating the corpora cavernosa and in neuronal plexuses in the adventitial layer of penile arteries. Small dose of NO synthetase inhibitors abolished electrophysiologically induced penile erections. Ferrante et al. ${ }^{25}$ reported that NADPH diaphorase positive neurons were selectively spared in neurodegenerative diseases such as Huntington's diseases. Huang et $\mathrm{al}^{19}$ reported that mice lacking nitric oxide synthase (NOS) gene developed grossly enlarged stomachs with hypertrophy of the pyloric sphincter and the circular muscle layer, resembling infantile pyloric stenosis in human, in which gastric outlet obstruction was associated with the lack of NADPH diaphorase neurons in the pylorus. Hatano et $\mathrm{al}^{26}$ and Shirasawa et $\mathrm{al}^{6}$ reported that mice lacking Ncx/Hox $11 \mathrm{~L} .1$ gene developed megacolon with hyperinnervated enteric ganglia. Those mice can be used as a model for human neuronal intestinal dysplasia (NID) diseases, in which myenteric neuronal hyperplasia and megacolon are seen. Finally the impact of the results of researches in nitric oxide on clinical aspect of diseases, in which nitric oxide (NO) may play a special role as the cause, is very important and might be useful to find the therapy for such diseases.

\section{CONCLUSION}

The numerous groups of NADPH diaphorase positive neuronal cells were detected along all parts of the digestive tract, including esophagus, stomach, small and large intestine as well as urinary bladder. These cells existed in a very small number in the submucous plexuses of Meissner located in the submucous layer, and ubiquitous in myenteric plexuses of Auerbach located in the area between the external and internal layer of the smooth muscle of the digestive tract. In the bladder, those cells existed at the bladder neck, inside of the muscle coat of urinary bladder.

Since the number of NADPH diaphorase positive neuronal cells per millimeter square is more numerous in stomach and large intestine, there is a possibility that the amount of nitric oxide in those organs is also higher. This fact suggests the important role of nitric oxide (NO) in those organs. Furthermore, the existence of those cells in the limited area of urinary bladder i.e. in the bladder neck may be correlated with the function of nitric oxide (NO) for vesico-urethral sphincter muscle.

\section{Acknowledgements}

The author would like to express the appreciation and special thank to Dr. Masahiko Hatano MD, Division of Developmental Genetics, Chiba University, Graduate School of Medicine, for his kind technical guidance, and the supply of animals and materials; and to Mrs. W. Indarty Aulia for her help in preparing and typing this manuscript.

\section{REFERENCES}

1. Synder SH. Nitric oxide: first in a new class of neurotransmitter? Science 1992;257:494-6.

2. Dimmeler S, Lottspeich F, Brune B. Nitric oxide cause ADP-ribosylation and inhibition of glyceraldehyde-3phosphate dehydrogenase. J Biol Chem 1992; 267:16771-4.

3. Kots AY, Skurat AV, Sergienko EA, Bulargina TV, Severin ES. Nitroprusside stimulated the cysteine-spesific mono (ADP-ribosylation) of glyceraldehyde-3-phosphate dehydrogenase from human erythrocytes. FEBS Lett 1992; 300:9-12.

4. Mc Donald LJ, Moss J. Stimulation by nitric oxide of an NAD linkage to glyceraldehyde-3-dehydrogenase. Proc Natl Acad Sci USA 1993; 90:6238-41.

5. Marletta MA. Nitric oxide synthase structure and mechanism. J Biol Chem 1993; 268:12231-4.

6. Shirasawa S, Yunker AMR, Roth KA, Brown GA, Homing S, Korsmeyer SJ. Enx (Hox 11L.1)-deficient mice develop myenteric neuronal hyperplasia and megacolon. Nature Medicine 1997; 3(6):646-50.

7. Dawson TM, Bredt DS, Fotuhi M, Hwang PM, Snyder SH. Nitric oxide synthase and neuronal NADPH diaphorase are identical in brain and peripheral tissues. Proc Natl Acad Sci USA 1991; 88:7797-801.

8. Bredt DS, Glatt CE, Hwang PM, Fotuhi M, Dawson TM, Snyder SH. Nitric oxide synthase protein and mRNA are discretely localized in neuronal populations of the mammalian CNS together with NADPH diaphorase. Neuron 1991; 7:615-24.

9. Hope BT, Michael GJ, Knigge KM, Vincent SR. Neuronal NADPH diaphorase is a nitric oxide synthase. Proc Natl Acad Sci USA 1991; 88:2811-4.

10. Knowles RG, Palacios M, Palmer RMJ, Moncada S. Formation of nitric oxide from L-arginine in the central nervous system: a transduction mechanism for stimulation of the soluble guanylate cyclase. Proc Natl Acad Sci USA 1989; 86:5159-62.

11. Scherer-Singler U, Vincent SR, Kimura H, McGeer EG. J Neuroscience Methods 1983; 9:229-34.

12. Bredt DS, Snyder SH. Nitric oxide, a novel neuronal messenger (Review). Neuron 1992; 8:3-11.

13. Stuehr DJ, Kwon NS, Nathan Cr, Griffth OW. Nwhydroxyl-L-arginine is an intermediate in the biosynthesis of nitric oxide from L-arginine. J Biol Chem 1991; 266:6259-63. 
14. Hope BT, Vincent SR. Histochemical characterization of neuronal NADPH-diaphorase. J Histochem Cytochem $1989 ; 37: 653-61$.

15. Bredt DS, Hwang PM, Snyder SH. Localization of nitric oxide synthase indicating a neural role for nitric oxide. Nature 1990; 347:768-70.

16. Gabella G. Intra mural neurons in the urinary bladder of Guinea pig. Cell Tiss Res 1990; 261:231-7.

17. Grozdanovic Z, Baumgarten HG, Bruning G. Histochemistry of NADPH-diaphorase, a marker for neuronal nitric oxide synthase, in the peripheral autonomic nervous system of the mouse. Neuroscience 1992;48(1):225-35.

18. Bult H, Boeckxstaens GE, Pelckmans PA, Jordaens FH, Van Maercke YM, Herman AG. Nitric oxide as an inhibitory non-adrenergic non-cholinergic neuro-transmitter. Nature 1990; 345:346-7.

19. Huang PL, Dawson TM, Bredt DS, Snyder SH, Fishman MC. Target disruption of the neuronal nitric oxide synthase gene. Cell 1993; 75:1273.

20. Keef KD, Shuttleworth CW, Xue C, Bayquinov O, Publicover NG, Sander KM. Relationship between nitric oxide and vasoactive intestinal polypeptide in enteric inhibitory neurotransmission. Neuropharmacology 1994; 33:1303.

21. Mevorach RA, Bogaert GA, Kogan BA. Role of nitric oxide in fetal lower urinary tract function. J Urol 1994; 152:510.

22. Persson K, Igawa Y, Mattiason A, Andersson KE. Effect of inhibition of the L-arginine/nitric oxide pathway in the rat lower urinary tract in vivo and invitro. $\mathrm{Br} \mathrm{J}$ Pharmacol 1992; 107:78.

23. Behar J, Biancani P. Effect of cholecystokinin and the octapeptide of cholecystokinin on the feline sphincter of Oddi and gallbladder. J Clin Invest 1980; 66:1231-9.

24. Bumett AL, Lowenstein CJ, Bredt DS, Chang TSK, Snyder SH. Nitric oxide: a physiologic mediator of penile erection. Science 1992; 257:401-3.

25. Ferrante RJ, Kowall NW, Beal MF, Richardson EP Jr, Bird ED, Martin JB. Selective sparing of a class of striatal neurons in Huntington's diseases. Science 1985: 230:561-3.

26. Hatano M, Aoki T, Dezawa M, Yusa S, litsuka Y, Koseki $\mathrm{H}$, et al. A novel pathogenesis of megacolon in Ncx/Hox 11L.1 deficient mice. J Clin Invest 1997; 100(4):795-801. 